\title{
Demographic, clinical and microbiological characteristics of maternity patients: A Canadian clinical cohort study
}

\author{
Wanda M Wenman $M D^{1,5}$, Ivanna V Tataryn $\mathrm{MD}^{2}$, Michel R Joffres MD PhD ${ }^{1}$, \\ Rachelle Pearson $\mathrm{RN}^{1,2}$, Michael GA Grace $\mathrm{PhD}^{3,4}$, William L Albritton MD PhD ${ }^{1,5}$, \\ Errol Prasad $\mathrm{MSC}^{5}$ and The Edmonton Perinatal Infections Group*
}

WM Wenman, IV Tataryn, MR Joffres, et al. Demographic, clinical and microbiological characteristics of maternity patients: A Canadian clinical cohort study. Can J Infect Dis 2002;13(5):311-318.

OBJECTIVE: To determine the demographic, clinical and microbiological characteristics of a representative Canadian obstetrical population.

DESIGN: A one-year cohort study of all maternity patients who were followed to delivery, using detailed patient questionnaires containing more than 60 demographic and clinical variables, and three microbiological evaluations during gestation - first trimester, 26 to 30 weeks, and labour and delivery. Outcome measurements included birth weight and gestational age.

SETTING: Labour and delivery suites of all office obstetrical practices affiliated with a single hospital.

POPULATION STUDIED: A consecutive sample of pregnant women in the study practices during one year were eligible for enrolment; 2237 consecutive patients were approached for consent, 2047 enrolled and 1811 completed the study through delivery.

RESULTS: The average patient was white, married and 29 years of age. Slightly more than half of the patients had postsecondary education, but $10 \%$ fell below the national poverty line for income. Frequency of factors linked to adverse pregnancy outcomes included cigarette smoking (19\%), alcohol ingestion $(18 \%)$, previously having had a premature infant $(7 \%)$, and maternal diabetes (2\%). Overall prevalence of genital microbes variously implicated in prematurity was 37\% for ureaplasma, 11\% for group B streptococcus and 4\% for Mycoplasma hominis. Prevalence of bacterial vaginosis was $14 \%$. The median gestational age for the cohort was 39 weeks, with $7 \%$ of infants born less than 37 weeks' gestation. Mean birth weight was $3415 \mathrm{~g}$.

CONCLUSIONS: The present clinical cohort represents demographic and medical characteristics of the Canadian obstetrical population. The birth outcomes are consistent with national data. This database provides valuable information about a general obstetrical population that is managed by a universal health care system.

Key Words: Genital tract infections; Prematurity; Risk factors

Résumé à la page suivante

Departments of ${ }^{1}$ Pediatrics, ${ }^{2}$ Obstetrics and Gynecology, ${ }^{3}$ Radiology and ${ }^{4}$ Dentistry, University of Alberta, and ${ }^{5}$ Provincial Laboratory of Public Health for Northern Alberta, Edmonton, Alberta

*Drs JJ Boyd, RCM Chua, G Iwaniuk, A Lee, BF Mitchell, HD Mueller, KE Pearse, DWJ Reid, DK Still

Correspondence and reprints: Dr WM Wenman, Pediatric Infectious Diseases, University of California Davis, 2516 Stockton Boulevard,

Sacramento, California 95817, USA. Telephone 916-734-7618, fax 916-734-7890, e-mail wmwenman@ucdavis.edu

Received for publication June 4, 2001. Accepted October 1, 2001 


\section{Caractéristiques démographiques, cliniques et microbiologiques des patientes de maternité : Étude clinique sur une cohorte canadienne}

OBJECTIF : Déterminer les caractéristiques démographiques, cliniques et microbiologiques d'une population obstétricale canadienne représentative.

MODÈLE : Étude de cohorte d'une durée d'un an portant sur toutes les patientes de maternité qui ont été suivies jusqu'à l'accouchement à l'aide de questionnaires détaillés incluant plus de 60 variables démographiques et cliniques et trois évaluations microbiologiques, durant la gestation : premier trimestre, 26 à 30 semaines, puis travail et accouchement. Les mesures concernant l'issue de la grossesse incluaient le poids à la naissance et l'âge gestationnel.

CONTEXTE : Salles de travail et salles d'accouchement de toutes les pratiques obstétricales affiliées à un seul hôpital.

POPULATION ÉTUDIÉE : Un échantillon de femmes enceintes consécutives suivies par les cabinets d'obstétrique participant à l'étude au cours d'un an a été jugé admissible pour inscription. Deux mille deux cent trente-sept patientes consécutives ont été abordées pour donner leur con- sentement; 2047 se sont inscrites et 1811 le sont restées jusqu'au moment de l'accouchement.

RÉSULTATS : En général, les patientes étaient de race blanche, mariées et âgées de 29 ans. Un peu plus de la moitié des patientes détenaient un diplôme post-secondaire, mais $10 \%$ se trouvaient sous le seuil de pauvreté national sur le plan du revenu. La fréquence des facteurs reliés à des complications de la grossesse incluait le tabagisme (19\%), l'alcoolisme (18\%), des antécédents d'accouchement prématuré $(7 \%)$ et le diabète de grossesse $(2 \%)$. La prévalence globale des agents pathogènes génitaux impliqués dans la prématurité a été de $37 \%$ pour l'uréaplasme, de $14 \%$ pour la vaginose bactérienne, de $11 \%$ pour le streptocoque du groupe B et de $4 \%$ pour Mycoplasma hominis. Lâge gestationnel médian pour la cohorte a été de 39 semaines, 7 \% des nourrissons étant nés après moins de 37 semaines de gestation. Le poids moyen à la naissance était de 3415 grammes.

CONCLUSION : La cohorte clinique actuelle représente les caractéristiques démographiques et médicales de la population obstétricale canadienne. L'issue sur le plan des naissances concorde avec les données nationales. Cette base de données procure des renseignements utiles sur la population obstétricale générale prise en charge par le système de santé universel.
$\mathrm{P}^{\mathrm{r}}$ remature birth $(\mathrm{PB})$, defined as occurring at less than 37 weeks' gestation, is the leading cause of perinatal mortality and morbidity in the industrialized world $(1,2)$. Despite this recognition and advances in perinatal care, the prevalence of $\mathrm{PB}$ in the developed world has increased in recent years (3-6). The medical and economic impact of $\mathrm{PB}$ is appreciated specifically in the perinatal and/or neonatal periods, but also continues throughout life.

Many factors, including socioeconomic, reproductive and medical conditions have been implicated in the etiology of $\mathrm{PB}(5,7)$. Infections have been increasingly recognized as important risk factors for PB (8-11). In some cases, such as with bacterial vaginosis, the stage of gestation during which infection occurs appears to be important in pregnancy outcome $(12,13)$. However, results from several studies have been inconsistent and confounding risk factors have often not been assessed $(10,14,15)$. Antibiotic treatment trials designed to eradicate infections to decrease the incidence of PB have yielded inconsistent results (14,16-21).

The majority of studies on PB, carefully conducted and sometimes including large numbers of patients, have involved high risk obstetrical populations, and the results may not necessarily be extrapolated to general populations (1). The purpose of the present study was to evaluate a general obstetrical cohort population and to ultimately assess genital infections at various stages of pregnancy, including labour, in conjunction with other potential risk factors related to PB or low birth weight (less than $2500 \mathrm{~g}$ ).

\section{DATA AND METHODS}

\section{Facilities}

The present study was conducted at three private obstetrical offices, one hospital-based office, and the University of Alberta Hospital (UAH), Edmonton, Alberta. The four offices comprised 10 obstetricians who each enrolled between 108 and 382 patients (one primarily administra- tive physician enrolled two patients). All patients who were due for delivery over a 12 -month consecutive period between 1994 and 1995 were asked to participate. All microbiological testing was performed on site; Gram stains and bacterial cultures were performed at the UAH laboratories; and serology, chlamydial and mycoplasma cultures were performed at the Provincial Laboratory of Public Health for Northern Alberta. Both laboratories are housed within the UAH complex.

\section{Enrolment and data collection}

The study was approved by the ethics committee, Faculty of Medicine, University of Alberta. All prenatal patients who were seen for a first visit before 20 weeks' gestation at each one of the four obstetrical offices associated with UAH were asked to provide informed consent and to enrol in the study. The obstetrical risk questionnaire was developed, tested and finalized. A pilot project using the questionnaire was conducted to elicit feedback from patients, staff and methodologists before the study onset. Patients were introduced to the study by the research nurse, who explained the questionnaire in the physician's office before the patient was seen by the obstetrician. The same research nurse enrolled in excess of $90 \%$ of all study patients, while the remainder were enrolled by one other nurse.

Sealed boxes were left in each obstetrician's office to allow patients to deposit their completed questionnaires. Each envelope accompanying the questionnaire was numbered, and a master list containing the number and name of the patient was checked. If the questionnaire was not received, a maximum of three follow-up telephone calls were made to remind the patient to bring it to the office. If the original questionnaire was misplaced by the patient, another was mailed to her for completion and she was asked to deposit it in the box at the next prenatal office visit. 
The study nurse then contacted and interviewed each patient with regard to obstetrical risk factors. Demographic and obstetrical variables associated with PB from previous studies included maternal age, race, parity, marital status, welfare status, cigarette smoking, alcohol and other drug consumption, previous preterm delivery, urinary and genital tract infections, and nutritional status. Clinical variables such as underlying medical conditions, medications, reproductive history and obstetrical data were collected. Questionnaires took from 10 to $40 \mathrm{~min}$ to complete. Additional information was taken from the obstetrical charts and completed by the study nurse. More than 60 variables, many of which had numerous categories, were documented in the database. Standardization of the questionnaire was ascertained by mailing 50 repeat questionnaires to enrolled patients to compare responses to those given at their first visit.

All data were entered into an SPSS (SPSS Inc, USA) file and verified with sample checks that were conducted to ensure a minimization of coding and validity errors. Descriptive statistics were calculated for each variable at each time period with appropriate adjustments made for incomplete cases.

\section{Microbiology}

Each patient enrolled in the study had three speculum examinations, and microbiological investigations were performed on the specimens that were collected. The first examination occurred at the initial visit to the obstetrician's office during the first trimester. At that time, urine culture and serology for syphilis, hepatitis B and rubella were performed. Genital cultures for Neisseira gonorrhoeae, Chlamydia trachomatis, group B streptococcus, Mycoplasma hominis and Ureaplasma urealyticum, and Gram stains for bacterial vaginosis, trichomonas-like organisms and yeast were performed. The second examination took place in the obstetrician's office between 26 and 30 weeks' gestation. At this visit, cultures were done for $\mathrm{C}$ trachomatis, group $\mathrm{B}$ streptococcus, $M$ hominis and $U$ urealyticum, and a Gram stain was performed for the purposes noted above. The third examination took place in the hospital at the time of labour and delivery; the specimens that were collected and the microbiology that was performed were the same as those of the second examination. All specimens were delivered to the laboratory within $2 \mathrm{~h}$ of collection. Bacterial cultures were plated when received, chlamydia cultures were set up within $8 \mathrm{~h}$ of receipt and mycoplasma cultures were set up within $24 \mathrm{~h}$ of receipt.

For gonococcal cultures, endocervical swabs were placed in charcoal transport medium and inoculated onto modified Thayer-Martin split plates and incubated in carbon dioxide at $35^{\circ} \mathrm{C}$. Isolates were identified by standard methods, including Gram smear, oxidise reactivity, direct fluorescent antigen identification (SYVA reagent [Syva Diagnostics, USA]) and the presence of beta lactamase. Equivocal or fluorescent antigen-negative isolates were then selected on cysteine trypticase agar (glucose, maltose, sucrose), ortho- nitrophenol-beta-galactopyranoside and catalase. Cervicovaginal swabs for isolation of group B streptococcus were placed in charcoal transport medium and inoculated onto $5 \%$ blood agar plates for identification by standard methods, including Gram smear and grouping (PathoDx Streptococcus grouping kit, Diagnostic Products Corporation, USA). Endocervical specimens were collected using a rayon fibre swab for $\mathrm{C}$ trachomatis, $\mathrm{M}$ hominis and $U$ urealyticum, and were placed into sucrose-phosphate-glutamate transport medium. C trachomatis cultures were set up within $8 \mathrm{~h}$ of receipt by the laboratory. Samples were inoculated onto cycloheximide-treated McCoy cell monolayers in shell vials and incubated in carbon dioxide at $37^{\circ} \mathrm{C}$. After $48 \mathrm{~h}$, the monolayers were stained with fluoresceinconjugated antichlamydial monoclonal antibody (Kallestad Laboratories Inc, USA), and inclusions were identified by fluorescent microscopy.

For the isolation of $\mathrm{M}$ hominis and $U$ urealyticum, the specimens were inoculated onto both genital mycoplasma agar plates and bromothymol blue broth. The plates were incubated for $48 \mathrm{~h}$ (in $5 \%$ carbon dioxide for agar) at $37^{\circ} \mathrm{C}$ and the broths at $37^{\circ} \mathrm{C}$ in air for the same period. The bromothymol blue broth comprised pleuropneumonia-like organisims broth yeast extract, bromothymol blue solution $0.4 \%$, donor horse serum, urea solution $10 \%$ and tripeptide, and was supplemented with penicillin and nystatin. The agar plates contained the same ingredients in addition to agar. $U$ urealyticum colonies were identified with urease spot test reagent. $\mathrm{M}$ hominis was identified by colonial morphology and substrate utilization, the latter by subculturing bromothymol blue broth into glucose/arginine subcultures (M hominis hydrolyzes arginine [colour changes in arginine broth], but does not ferment glucose).

A vaginal swab for Gram stain was smeared on a glass slide and immediately air dried unfixed. The slide was stained and assessed for trichomonas-like organisms, clue cells, yeast-like organisms and Nugent's (22) criteria for bacterial vaginosis.

\section{RESULTS}

A total of 2237 consecutive patients were asked by the research nurse to participate in the study and were provided questionnaires. Questionnaires were not returned by 188 patients at the enrolment stage, and two women consented to be in the study but did not hand in the questionnaire, which left 2047 (91.5\%) women with some questionnaire information. Fifty-four women moved away from the area during their pregnancies, and nine either refused to continue in the study or could not be contacted following enrolment. For some variables, missing data were not included in the denominator, and totals in the tables may vary according to the level of information that was available.

Demographic characteristics of the 2047 women who completed the questionnaire are shown in Table 1. Age was 29.1 years $( \pm 5.1)$, and the majority of women were married $(81 \%)$, white $(78 \%)$ and had attended college $(52 \%)$. Principal occupations were skilled (31\%), professional 
TABLE 1

Demographic characteristics of participants in the Edmonton Perinatal Study

\begin{tabular}{|c|c|c|}
\hline Characteristics & $\begin{array}{c}\text { Number of } \\
\text { participants }\end{array}$ & Percentage \\
\hline \multicolumn{3}{|l|}{ Marital status } \\
\hline Married & 1641 & 81.0 \\
\hline Common law partner & 254 & 12.5 \\
\hline Single (never married) & 98 & 4.8 \\
\hline Widowed, separated or divorced & 32 & 1.6 \\
\hline \multicolumn{3}{|l|}{ Ethnic or racial group } \\
\hline White & 1531 & 77.5 \\
\hline Asian & 182 & 9.2 \\
\hline East Indian & 62 & 3.1 \\
\hline Black & 33 & 1.7 \\
\hline Native Indian & 45 & 2.3 \\
\hline Métis & 25 & 1.3 \\
\hline Inuit & 1 & 0.1 \\
\hline Other & 107 & 5.4 \\
\hline Attended university (yes/no) & $1049 / 969$ & $52.0 / 48.0$ \\
\hline \multicolumn{3}{|l|}{ Occupation } \\
\hline Professional & 532 & 28.8 \\
\hline Clerical & 43 & 2.3 \\
\hline Skilled & 563 & 30.5 \\
\hline Unskilled & 204 & 11.1 \\
\hline Manager & 37 & 2.0 \\
\hline Homemaker & 346 & 18.8 \\
\hline Student & 120 & 6.5 \\
\hline \multicolumn{3}{|l|}{ Household income } \\
\hline Less than $\$ 12,000$ & 176 & 9.7 \\
\hline$\$ 12,000$ to $\$ 24,999$ & 288 & 15.9 \\
\hline$\$ 25,000$ to $\$ 49,999$ & 590 & 32.5 \\
\hline$\$ 50,000$ or more & 762 & 42.0 \\
\hline
\end{tabular}

Mean age of participants was 29.1 years, $S D \pm 5.1$ years

(29\%) and homemaker (19\%). Forty-two per cent reported more than $\$ 50,000$ household income/year and 10\% fell below the national poverty line.

No single medical condition was noted in more than $4 \%$ of the study group (Table 2). High blood pressure and high cholesterol were described by $3.6 \%$ of participants. There were 46 patients with diabetes, of whom $54 \%$ were taking insulin. Nearly 2\% of all subjects were taking antibiotics.

Table 3 shows cigarette and drug consumption, including alcohol, during the current pregnancy $-14 \%$ smoked cigarettes daily and nearly 5\% smoked occasionally. Since becoming aware that they were pregnant, $18 \%$ of women had ingested alcohol. Although $18 \%$ of the women in the study reported having used street drugs at one point, fewer than $1 \%$ still used these drugs.

Nutrition and exercise information is shown in Table 4. Meal consumption patterns revealed that supper was the most likely meal of the day (98\%), and breakfast was the least likely (83\%). Daily exercise before the current preg-
TABLE 2

Medical history of participants in the Edmonton Perinatal Study

\begin{tabular}{lcc}
\hline History & $\begin{array}{c}\text { Number of } \\
\text { participants } \\
\text { (yes/no) }\end{array}$ & $\begin{array}{c}\text { Percentage } \\
\text { (yes/no) }\end{array}$ \\
\hline Medical condition & & \\
High blood pressure & $73 / 1941$ & $3.6 / 96.4$ \\
High cholesterol & $73 / 1943$ & $3.6 / 96.4$ \\
Thyroid disease & $52 / 1961$ & $2.6 / 97.4$ \\
Diabetes & $46 / 1967$ & $2.3 / 97.7$ \\
Kidney disease & $20 / 1993$ & $1.0 / 99.0$ \\
Heart disease & $14 / 1998$ & $0.7 / 99.3$ \\
Other & $168 / 1845$ & $8.3 / 91.7$ \\
& & \\
Diabetes treatment & & \\
None & $4 / 42$ & $8.7 / 91.3$ \\
Diet & $29 / 17$ & $63 / 37$ \\
Insulin & $25 / 21$ & $54.3 / 45.7$ \\
& & \\
Present medications and/or supplements & & \\
Vitamins & $1074 / 957$ & $52.9 / 47.1$ \\
Iron & $240 / 1791$ & $11.8 / 88.2$ \\
Folic acid & $190 / 1841$ & $9.4 / 90.6$ \\
Over the counter medications & $84 / 1947$ & $4.1 / 95.9$ \\
Acetylsalicylic acid & $63 / 1968$ & $3.1 / 96.9$ \\
Antihypertensive drugs & $44 / 2193$ & $2.0 / 98.0$ \\
Antibiotics & $36 / 1995$ & $1.8 / 98.2$ \\
Hormones & $31 / 2000$ & $1.5 / 98.5$ \\
\end{tabular}

TABLE 3

History of cigarette, alcohol and drug use of participants in the Edmonton Perinatal Study

\begin{tabular}{lcc}
\hline Usage & $\begin{array}{c}\text { Number of } \\
\text { participants }\end{array}$ & Percentage \\
\hline Current cigarette smoking & & \\
$\quad$ Daily & 284 & 13.9 \\
Occasionally & 95 & 4.7 \\
None & 1662 & 81.4 \\
& & \\
Alcohol ingestion since becoming & & \\
$\quad$ aware of pregnancy (yes/no) & $348 / 1643$ & $17.5 / 82.5$ \\
$\quad$ Weekly (yes/no) & $59 / 1932$ & $3.0 / 97.0$ \\
$\quad$ Monthly (yes/no) & $122 / 1869$ & $6.1 / 93.9$ \\
$\quad$ Less than once/month (yes/no) & $175 / 1816$ & $8.8 / 91.2$ \\
& & \\
Street drugs ever used (yes/no) & $362 / 1675$ & $17.8 / 82.2$ \\
Still using street drugs (yes/no) & $10 / 1980$ & $0.5 / 99.5$ \\
\hline
\end{tabular}

nancy was reported by $23 \%$ of the women, most commonly for a duration of 15 to $30 \mathrm{~min}(50 \%)$ or 31 to $60 \mathrm{~min}(35 \%)$. Approximately $50 \%$ of the patients reported that they exercised less since they became pregnant, while 30\% did not alter their exercise patterns. 
TABLE 4

Nutrition and exercise habits of participants in the Edmonton Perinatal Study

\begin{tabular}{|c|c|c|}
\hline Habit & $\begin{array}{l}\text { Number of } \\
\text { participants }\end{array}$ & Percentage \\
\hline \multicolumn{3}{|l|}{ Meal consumption (yes/no) } \\
\hline Breakfast & $1693 / 338$ & $83.4 / 16.6$ \\
\hline Lunch & $1935 / 108$ & $94.7 / 5.3$ \\
\hline Supper/Dinner & $2002 / 39$ & $98.1 / 1.9$ \\
\hline Snacks & $1658 / 383$ & $81.2 / 18.8$ \\
\hline \multicolumn{3}{|l|}{ Exercise regularly before } \\
\hline pregnancy (yes/no) & $442 / 1502$ & $22.7 / 77.3$ \\
\hline \multicolumn{3}{|c|}{$\begin{array}{l}\text { Strenuous exercise causes sweating } \\
\text { and/or heavy breathing before pregnancy }\end{array}$} \\
\hline Most & 496 & 32.8 \\
\hline Some & 867 & 57.3 \\
\hline None & 150 & 9.9 \\
\hline \multicolumn{3}{|c|}{ Length of exercise before pregnancy } \\
\hline Less than $15 \mathrm{~min}$ & 99 & 6.7 \\
\hline 15 to $30 \mathrm{~min}$ & 741 & 50.1 \\
\hline 31 to $60 \mathrm{~min}$ & 514 & 34.8 \\
\hline More than $60 \mathrm{~min}$ & 124 & 8.4 \\
\hline \multicolumn{3}{|l|}{ Exercise during pregnancy } \\
\hline More & 40 & 2.6 \\
\hline Same & 461 & 30.2 \\
\hline Less & 752 & 49.3 \\
\hline None & 272 & 17.8 \\
\hline \multicolumn{3}{|c|}{ Work requires strenous physical activity } \\
\hline Yes/no & $391 / 1391$ & $19.9 / 70.9$ \\
\hline Do not know or not applicable & 179 & 9.1 \\
\hline
\end{tabular}

The reproductive information in Table 5 indicates that the current pregnancy was the first pregnancy for $31 \%$ of the patients. Of those who had been pregnant previously, the number of pregnancies ranged from one $(47 \%)$ to five or more $(5 \%)$. The patient's age at first pregnancy was reported to be older than 20 years by $80 \%$ of respondents, and between 15 and 19 years by $20 \%$ of respondents. The mean age at first intercourse was 18 years. The number of lifetime sexual partners ranged from one $(37 \%)$ to more than 20 (3\%). Fewer than $2 \%$ of patients reported having more than one sexual partner during the current pregnancy. The majority $(87 \%)$ had used birth control within the six months before the current pregnancy, with oral contraceptives (48\%) and condoms (53\%) being the most commonly reported methods. Most women were able to conceive the current pregnancy in fewer than six months $(74 \%)$ or between six and 12 months (11\%). One-hundred-forty-three women (7\%) underwent investigations for infertility, and 114 (5.6\%) took fertility drugs to conceive the present pregnancy.
TABLE 5

Reproductive history of participants in the Edmonton Perinatal Study

\begin{tabular}{lcc}
\hline Reproductive history & $\begin{array}{c}\text { Number of } \\
\text { participants }\end{array}$ & Percentage \\
\hline Previous pregnancies (yes/no) & $1385 / 622$ & $69.0 / 31.0$
\end{tabular}

Number of previous pregnancies

$\begin{array}{lll}\text { One } & 647 & 46.7\end{array}$

$\begin{array}{lll}\text { Two } & 401 & 29.0\end{array}$

$\begin{array}{lll}\text { Three } & 197 & 14.2\end{array}$

$\begin{array}{lll}\text { Four } & 67 & 4.8\end{array}$

More than five $\quad 73 \quad 5.3$

Type of previous pregnancy (total pregnancies $=2724$ )

Full term $\quad 1324$

$\begin{array}{lll}\text { Premature } & 187 & 6.9\end{array}$

Stillbirth $\quad 26 \quad 1.0$

Miscarriage $\quad 666 \quad 24.4$

Induced abortion $\quad 287 \quad 10.5$

Do not know $\quad 234$

Age at first pregnancy (median age at first intercourse $=18$ years)

Younger than 15 years $\quad 11 \quad 0.1$

$15-19$ years $279 \quad 20.0$

20 years or older $\quad 1104 \quad 79.2$

Number of sexual partners

One

Two to 10

11 to 20

More than 20

54.5

$103 \quad 5.5$

More than one sexual partner during present pregnancy (yes/no)

$33 / 1968$

$1.6 / 98.4$

Birth control used in previous six months (yes/no)

$1747 / 270$

$86.6 / 13.4$

Type of birth control used (yes/no)

Pill

Condom

Diaphragm

Rhythm

Intrauterine device

Foam or sponge

Withdrawal

Other

$961 / 1052 \quad 47.7 / 52.3$

$1069 / 944 \quad 53.1 / 46.9$

69/1944 3.4/96.6

$193 / 1824 \quad 9.6 / 90.4$

$85 / 1928 \quad 4.2 / 95.8$

$151 / 1862 \quad 7.5 / 92.5$

$333 / 1684 \quad 16.5 / 83.5$

$32 / 1981 \quad 1.6 / 98.4$

Time to conceive pregnancy

Less than six months

Six to 12 months

12 to 24 months

25 to 60 months

More than 60 months

1435

74.4

$220 \quad 11.4$

$175 \quad 9.1$

$62 \quad 3.2$

$37 \quad 1.9$

Infertility investigation

or drugs (yes/no)

Drugs

205/1842 10.0/90.0

$114 / 1933 \quad 5.6 / 94.4$

Investigations

$\begin{array}{rr}143 / 1904 & 7.0 / 93.0 \\ 70 / 1977 & 3.4 / 96.6\end{array}$

Surgery

Treated for previous vaginal

infections (yes/no)

$1098 / 832 \quad 56.9 / 43.1$

Treatment for vaginal

infections this pregnancy (yes/no)

$173 / 1187$ 
TABLE 6

Obstetrical history of participants in the Edmonton Perinatal Study

\begin{tabular}{lcc}
\hline Obstetrical history & $\begin{array}{c}\text { Number of } \\
\text { participants }\end{array}$ & Percentage \\
\hline Mother or sister had premature baby & 385 & 22.0 \\
Previous twins or triplets & 23 & 1.7 \\
Previous vaginal bleeding & 493 & 35.6 \\
Cause of bleeding & & \\
Placenta previa & 22 & 4.5 \\
Abruption of the placenta & 18 & 3.7 \\
$\quad$ Other & 142 & 28.8 \\
$\quad$ Don't know & 311 & 63.1 \\
Incompetent cervix or cervical suture & & \\
$\quad$ in previous pregnancy & 35 & 2.5 \\
Previous caesarean section & 201 & 14.5 \\
\hline
\end{tabular}

Table 6 shows the obstetrical histories of patients who were enrolled in the study. Approximately $12 \%$ reported having previously had a premature baby, and $22 \%$ reported having a close female relative who had a premature infant. There was a history of twins or triplets in nearly $2 \%$ of the patients. Previous pregnancies had been complicated by vaginal bleeding in 36\% of patients and caesarean sections were performed in $15 \%$. An incompetent cervix or suture in the cervix during an earlier pregnancy was reported by $2.5 \%$ of patients.

Obstetrical data from the current pregnancy are presented in Table 7. At the time of the questionnaire, $38 \%$ of women had undergone an ultrasound. Vaginal bleeding was reported by $18 \%$ and an incompetent cervix or cervical suture was reported by $1 \%$ of patients during the current pregnancy.

Microbiology data from the three speculum examinations conducted during the current pregnancies are displayed in Table 8 . The principal organisms that were isolated, group B streptococcus, $U$ urealyticum and $\mathrm{M}$ hominis, occurred throughout pregnancy in $11 \%, 37 \%$ and $4 \%$ of patients, respectively. Bacterial vaginosis diagnosed by Gram stain criteria appeared to decrease slightly during gestation and was present in $17 \%$ of women at the first examination, $14 \%$ at the second examination and $12 \%$ at the time of labour and delivery. Only one patient had $N$ gonorrhoeae, which was isolated at the first prenatal visit. C trachomatis was also an uncommon isolate, detected in less than $1 \%$ of patients at any examination. Yeast-like organisms were observed on Gram stain in less than 10\% of patients at any examination.

Finally, pregnancy outcomes are shown in Table 9, with a mean gestational age of 38.9 weeks $( \pm 2.1)$, median 39 weeks; mean birth weight of $3384 \mathrm{~g}( \pm 583)$, median birth weight 3415 g. Overall, 127 (7\%) infants were born prema-
TABLE 7

Present obstetrical data of participants in the Edmonton Perinatal Study

\begin{tabular}{|c|c|c|}
\hline Obstetrical data & $\begin{array}{c}\text { Number of } \\
\text { participants }\end{array}$ & Percentage \\
\hline \multicolumn{3}{|l|}{ Ultrasound in this } \\
\hline pregnancy (yes/no) & $753 / 1226$ & $37.7 / 61.5$ \\
\hline \multicolumn{3}{|l|}{ Twins or triplets expected } \\
\hline (yes/no/do not know) & 22/907/504 & $1.5 / 63.3 / 35.2$ \\
\hline Vaginal bleeding (yes/no) & $353 / 1597$ & $18.1 / 81.9$ \\
\hline \multicolumn{3}{|c|}{ Cause and/or timing of bleeding (categories may overlap) } \\
\hline After intercourse & 43 & 12.2 \\
\hline After pelvic examination & 22 & 6.2 \\
\hline Placenta previa & 4 & 1.1 \\
\hline Abruption of placenta & 4 & 1.1 \\
\hline Other & 60 & 17.0 \\
\hline Don't know & 226 & 64.0 \\
\hline \multicolumn{3}{|l|}{ Incompetent cervix or } \\
\hline cervical suture & $19 / 1801$ & $1.0 / 99.0$ \\
\hline
\end{tabular}

turely. Caesarean section occurred in $16 \%$ of births, and $15 \%$ of infants were delivered with the assistance of forceps. Fetal distress occurred in $6 \%$ of cases and $7 \%$ of infants were admitted to the neonatal intensive care unit.

\section{DISCUSSION}

The goal of the present study was to enrol and track pregnant women prospectively, as a mechanism to determine the prevalence of demographic, clinical and microbiological factors. This approach has value relative to examining the importance of $\mathrm{PB}$ and the inconclusive information that has been available on its causation. $\mathrm{PB}$ is a significant and growing problem $(3,4,6)$. Infections represent one factor that is linked to adverse pregnancy outcome, and a preponderance of reports support an association between at least some microbes and PB. However, various studies have yielded conflicting results, even with syndromes such as bacterial vaginosis, which is most closely associated with prematurity $(15,18,20,21)$.

Most earlier North American studies enrolled lower socioeconomic and/or ethnically nonrepresentative populations. In addition, most were performed at publicly funded obstetrical clinics rather than at private practices and, thus, were unlikely to reflect a general obstetrical population. This has been the case even with larger multicentre studies. Therefore, we sought to assess a general Canadian obstetrical population by enrolling consecutive patients in the practices of a group (private and academic) comprising all obstetricians affiliated with a single hospital for infant 
TABLE 8

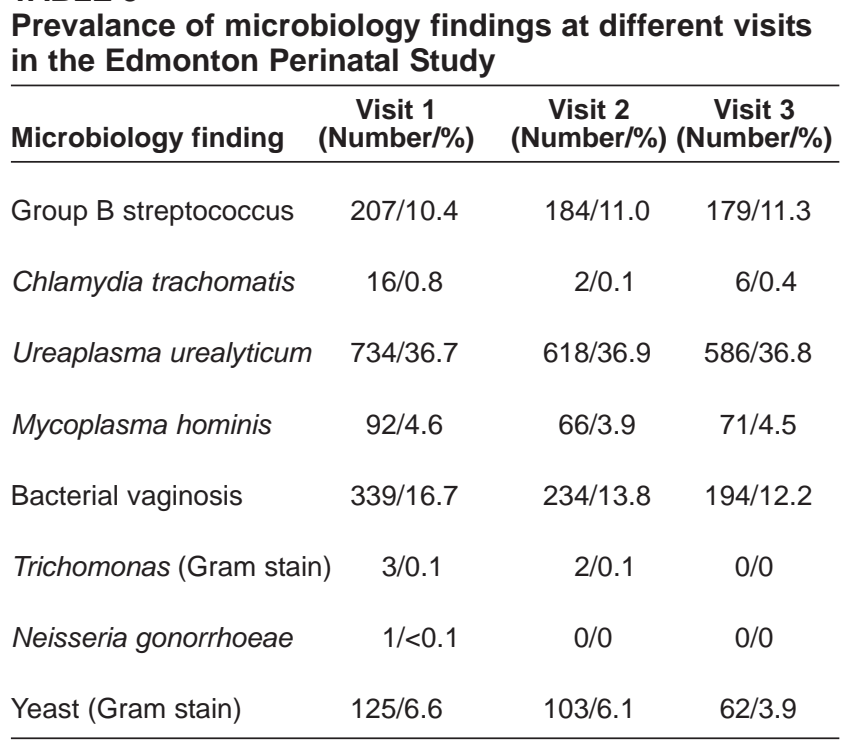

delivery. Patients routinely refer themselves to obstetricians, and the majority of maternal care in Edmonton is provided by specialists. In 1994 and 1995, obstetricians assisted in 10,337 deliveries, family practitioners assisted in 2876 and 'others', including midwives, assisted in 10 of the 13,223 births in the Edmonton region (23). The Perinatal Infections Group represented approximately $25 \%$ of obstetricians in Edmonton at the time of the study.

The study was designed to follow patients throughout pregnancy from initial enrolment, usually early in the first trimester, through delivery. An extensive laboratory evaluation was conducted in terms of the number of analyses and longitudinal sampling during the first trimester, second trimester and finally, labour and delivery. The present study also assessed other potential cofactors and confounding factors, including traits that are strongly linked to $\mathrm{PB}$, such as smoking and diabetes, and detailed information on nutrition, exercise and reproductive history.

Compared with the general population of Edmonton (24), the patient cohort in the present study was representative of the age distribution for pregnancy in this city. It was, however, a group with a higher educational achievement and economic level than that of the city of Edmonton or the Canadian population (24). Compared with data from other Canadian provinces, it appears that the prevalence of known risk factors in the study population was representative of that in the other provinces. For example, the occurrence of smoking, alcohol ingestion and diabetes during pregnancy was highly similar in the group in the present study and in Manitoba (25).

The patient group in the study demonstrated several differences with published North American studies. The patient group in the present study reflected the racial and ethnic composition of both Edmonton and Canada in general. The 1996 census data identified 9.8\% of the female population of Edmonton and $5.0 \%$ of the female population
TABLE 9

Pregnancy outcomes of participants in the Edmonton Perinatal Study

\begin{tabular}{lcc}
\hline Pregnancy outcome & $\begin{array}{c}\text { Number of } \\
\text { participants }\end{array}$ & Percent \\
\hline Complications & & \\
$\quad$ Caesarean & 296 & 16.3 \\
Forceps, etc & 267 & 14.7 \\
Fetal distress & 109 & 6.0 \\
Bleeding & 143 & 7.9 \\
Baby in neonatal intensive & & \\
$\quad$ care unit (yes/no) & $125 / 1686$ & $6.9 / 93.1$ \\
\hline
\end{tabular}

Mean total gestational age of 1814 participants was 38.9 weeks, $S D \pm 2.1$ weeks; Mean total birth weight of 1811 participants was $3384 \mathrm{~g}$, SD $\pm 583 \mathrm{~g}$

of Canada to be of Chinese, Vietnamese, Laotian, Cambodian, Japanese, Korean or Filipino ethnicity (24). The patients in the present study identified themselves as Oriental in $9.2 \%$ of instances, a proportion that was very similar to that of the census statistics. The census data reported that $3.6 \%$ of the female population of Edmonton was of South Asian (India and Pakistan) origin, 1.6\% black (Africa or Caribbean) and 4.3\% Aboriginal. The study cohort reported $3.1 \%, 1.7 \%$ and $3.7 \%$, respectively in the same groups. Because racial and/or ethnic information is not part of hospital admission or birth statistics, the census data best reflect the diversity of the obstetrical population in the present study. Most North American studies, including all large multicentre studies $(17,19,21,26-29)$, enrolled a predominance of 'minority' patients. In studies published since 1995, McGregor et al (27) reported a 66\% black or hispanic population, Meis et al (29) reported a 63\% black population, Hauth et al (20) reported a greater than $70 \%$ black population, and Carey et al (21) reported an $85 \%$ black or hispanic population. The few studies in which the majority of patients were white $(14,15,30)$ had a small enrolment and were single centre studies in which the majority of women were from low socioeconomic groups. For example, in one study (15) all patients attended publicly financed clinics, and in another study (30), $70 \%$ of patients received public assistance. Fewer than $50 \%$ of the subjects were married in all studies. In addition, several studies represented high risk obstetrical populations in which patients had a higher than average number of previous premature infants $(20,29)$.

Thus, the present study comprised a population with characteristics that were quite representative of the general Canadian obstetrical population in terms of race, ethnicity and obstetrical risk factors. One unique feature of the present study was that it offered a vehicle with which to assess the impact of universal medical insurance on PBs and related issues. In general, patients who are cared for under a socialized medical system are typical of the general population in terms of health care, including access.

The present study encompassed other features such as consecutive patient entry, nearly universal participation, 
and involvement of every obstetrician who provided care at a single hospital. It included a subset of patients with known high risk pregnancies because UAH was the tertiary obstetrical facility in northern Alberta at the time of the study. All of these characteristics, plus detailed histories, extensive microbiology, and comprehensive follow-up generated a substantial database that is being analyzed to eval- uate the role(s) of multiple variables in determining birth weight and gestational age.

ACKNOWLEDGEMENTS: The authors thank the patients for their participation in the study, the late Dr John Waters, Provincial Epidemiologist, for assistance, and the Children's Hospital Foundation (Alberta) for grant support.

\section{REFERENCES}

1. Lamont R. Antibiotics for the prevention of preterm birth. N Engl J Med 2000;342:581-2.

2. McCormack MC. The contribution of low birth weight to infant mortality and childhood morbidity. N Engl J Med 1985;312:82-90.

3. Joseph KS, Kramer M, Marcoux S, et al. Determinants of preterm birth rates in Canada from 1981 through 1983 and from 1992 through 1994. N Engl J Med 1998;339:1432-8.

4. Goldenberg R, Rouse D. Prevention of premature birth. N Engl J Med 1998;339:313-20.

5. Morrison J. Preterm Birth: A puzzle worth solving. Obstet Gynecol 1990;76:5S-12S.

6. Canadian Council on Social Development. The Progress of Canada's Children into the Millennium. Ottawa: Canadian Council on Social Development, 1999.

7. Creasy RL. Preterm birth and prevention: Where are we? Am J Obstet Gynecol 1993;168:1223-30.

8. Hack M, Merkatz IR. Preterm delivery and low birth weight a dire legacy. N Engl J Med 1995;333:1772-4.

9. Andrews W, Goldenberg R, Hauth J. Preterm labor: Emerging role of genital tract infections. Infect Agents Dis 1995;4:196-211.

10. Goldenberg R, Andrews W, Yuan A, MacKay H, St Louis M. Sexually transmitted diseases and adverse outcomes of pregnancy. Clin Perinatol 1997;24:23-41.

11. Hillier S, Nugent R, Eschenbach D, et al. Association between bacterial vaginosis and preterm delivery of a low-birth-weight infant. N Engl J Med 1995;33:1737-42.

12. Kurki T, Sivonen A, Renkonen O, Savia E, Ylikorkala O. Bacterial vaginosis in early pregnancy and pregnancy outcome. Obstet Gynecol 1992;80:173-7.

13. Riduan J, Hillier SL, Utomo B, Wiknjosastro G, Linnan M, Kandun N. Bacterial vaginosis and prematurity in Indonesia: Association in early and late pregnancy. Am J Obstet Gynecol 1993;169:175-8.

14. McGregor J, French J, Richter R, et al. Cervicovaginal microflora and pregnancy outcome: Results of a double-blind, placebocontrolled trail of erythromycin treatment. Am J Obstet Gynecol 1990;163:1580-91.

15. McGregor J, French J, Richter R, et al. Antenatal microbiologic and maternal risk factors associated with prematurity. Am J Obstet Gynecol 1990;163:1465-73.

16. Cohen I, Veille JC, Calkins B. Improved pregnancy outcome following successful treatment of chlamydial infection. JAMA 1990;263:3160-3.

17. Eschenbach D, Nugent R, Roa V, et al. A randomized placebocontrolled trial for the treatment of Ureaplasma eurealyicum to

prevent premature delivery. Am J Obstet Gynecol 1991;164:734-42.

18. Morales W, Schorr S, Albritton J. Effect of metronidazole in patients with preterm birth in preceding pregnancy and bacterial vaginosis: A placebo controlled, double blind study. Am J Obstet Gynecol 1994;171:345-9.

19. Klebanoff M, Regan J, Roa V, et al. Outcome of the vaginal infections and prematurity study: Results of a clinical trial of ethromycin among pregnant women colonized with group B streptococci. Am J Obstet Gynecol 1995;172:1540-5.

20. Hauth J, Goldenberg R, Andrews W, DuBard M, Copper R. Reduced incidence of preterm delivery with metronidazole and ethromycin in women with bacterial vaginosis. N Engl J Med 1995;333:1732-6.

21. Carey J, Klebanoff M, Hauth J, et al. Metronidazole to prevent preterm delivery in pregnant women with asympotomatic bacterial vaginosis. N Engl J Med 2000;342:534-40.

22. Nugent RP, Krohn M, Hillier SL. Reliability of diagnosing bacterial vaginosis is improved by a standardized method of Gram stain interpretation. J Clin Microbiol 1991;29:297-301.

23. Alberta Reproductive Health: Pregnancy Outcomes. Edmonton: Alberta Health \& Wellness, 1999.

24. Statistics for Edmonton (Census Metropolitan Area), Alberta. Statistics Canada, 1996. < http://www.statcan.ca/english/census01/ info/census96.cfm > Version current at July 5, 2002

25. Martens PJ. Being born in Manitoba: A look at prenatal health issues. In: The Health of Manitoba's Children. Winnipeg: Manitoba Center for Health Policy and Evaluation Report, 2001.

26. Alger LS, Lovchik JC, Hebel JR, Blackman LR, Crenshaw MC. The association of Chlamydia trachomatis, Neisseria gonorrhoeae and group B streptococci with preterm rupture of the membranes and pregnancy outcome. Am J Obstet Gynecol 1988;159:397-404.

27. McGregor JA, French JI, Parker R, et al. Prevention of premature birth by screening and treatment for common genital tract infections: Results of a prospective controlled evaluation. Am J Obstet Gynecol 1995;173:157-67.

28. Germain M, Krohn MA, Hillier SL, Eschenbach DA. Genital flora in pregnancy and its association with intrauterine growth retardation. J Clin Microbiol 1994;32:2162-8.

29. Meis PJ, Goldenberg RL, Mercer B, et al. The preterm prediction study: Significance of vaginal infections. Am J Obstet Gynecol 1995;173:1231-5.

30. Gravett M, Nelson P, DeRouen T, Crichlow C, Eschenbach D, Holmes K. Independent associations of bacterial vaginosis and Chlamydia trachomatis infection with adverse pregnancy outcome. JAMA 1986:256:1899-903. 


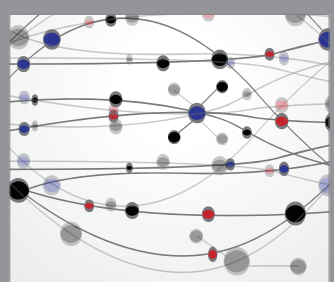

The Scientific World Journal
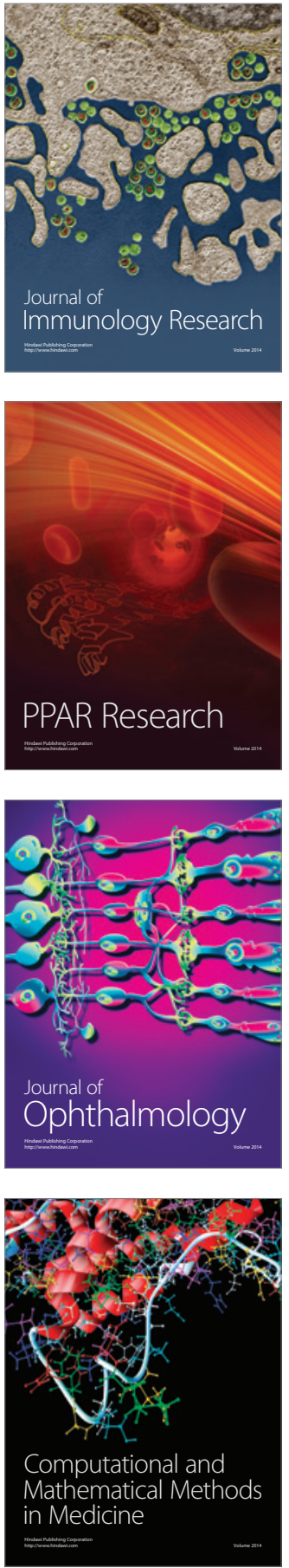

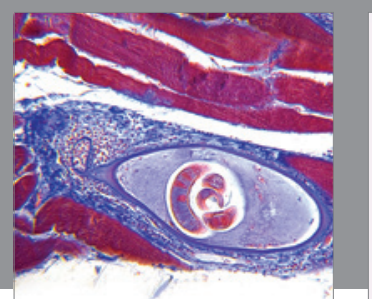

Gastroenterology Research and Practice

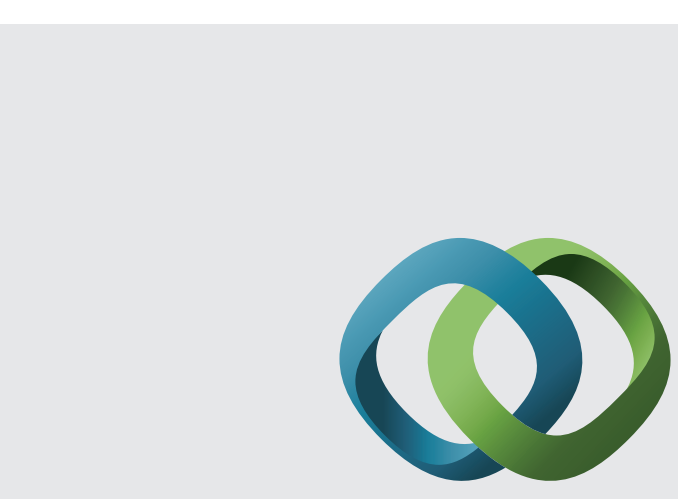

\section{Hindawi}

Submit your manuscripts at

http://www.hindawi.com
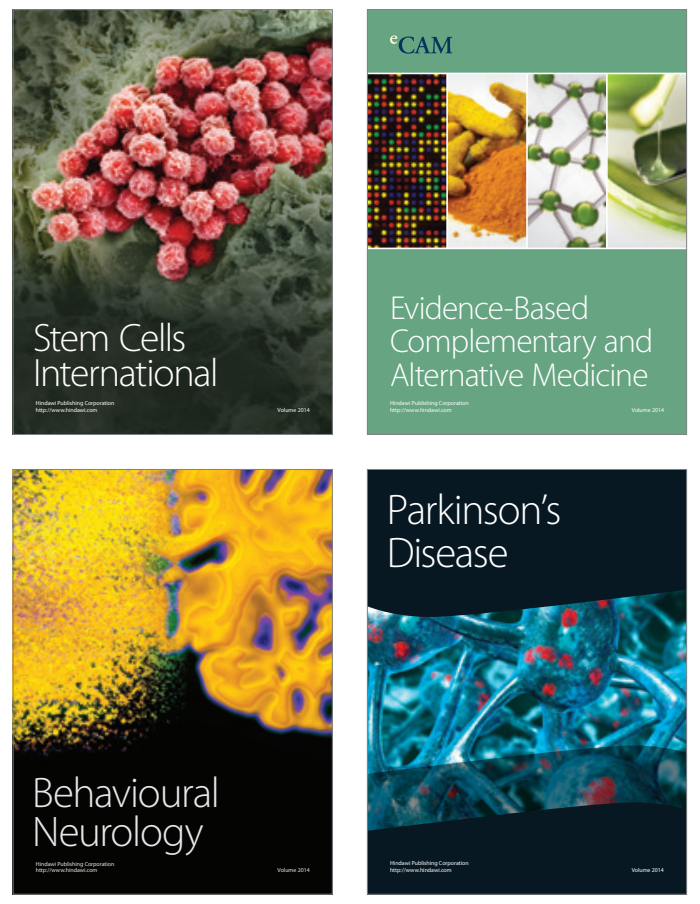
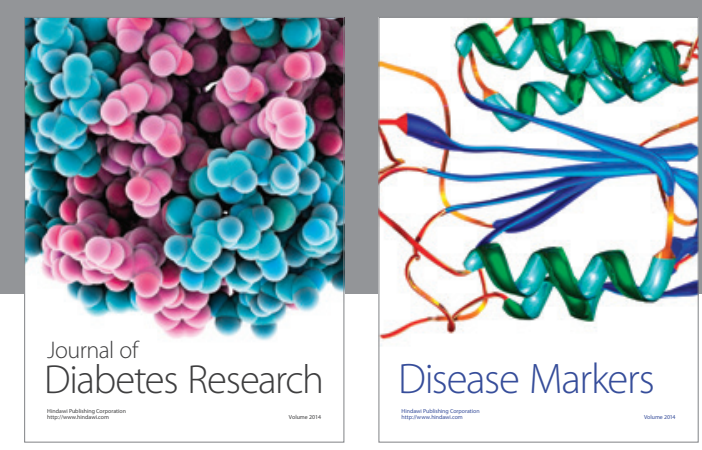

Disease Markers
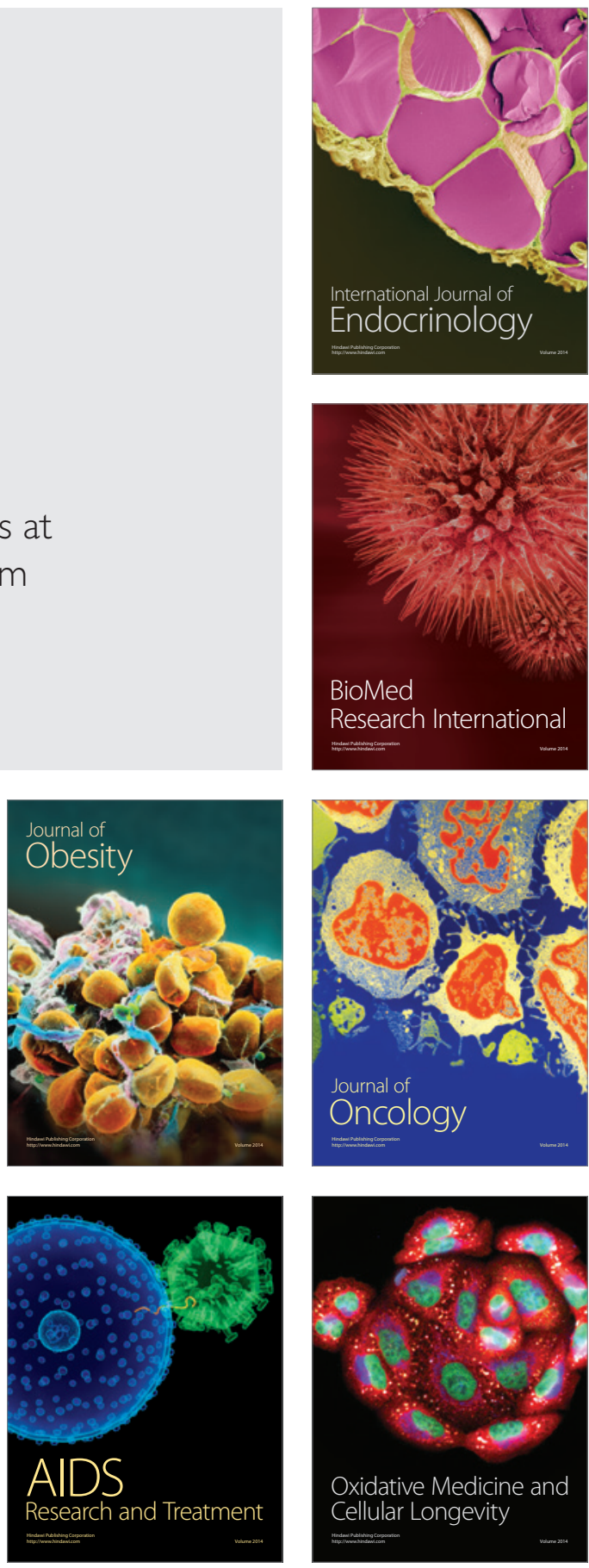